\title{
MEMAHAMI THEORY OF CONSTRAINT DARI SUMBER PERTAMA PEMBUMIAN KASUS NOVEL "THE GOALS"
}

\author{
Alwan Sri Kustono1 \\ Email: alwan.s@unej.ac.id
}

\begin{abstract}
This article is grounded The Goal (Goldratt \& Cox, 2008). It describes a case that occurred in a company. Manager has three months to change unprofitable and unreliable factory operations to succeed. It shows the differences that occur in a manufacturing company in a process, and how to discuss the difficulties that occur, and reduce their impact. Manager team discussed the challenges in the material flow, and immediately started requesting changes to help increase reserves and increase production. They brought an old machine that they received for free to increase the capacity of the engine, which has proven to be one of the two bottlenecks. Furthermore, they changed the process that happened to the company, changed like they did, which caused a great deal in getting the product and also caused some products to be heated several times to make it warmer and then even harder not just once or not at all.
\end{abstract}

Keywords: throughput, bottleneck, performance, constraint

\section{PROLOG}

\author{
Menanam bunga bagi pelukis adalah realisme keindahan \\ Menanam bunga bagi penyair adalah majas keelokan \\ Menanam bunga bagi penyanyi adalah acapella kemerduan \\ Menanam bunga bagi akuntan adalah pengakuan beban
}

Pagi itu Tn. Subiakto, wakil presiden divisi manufaktur Perusahaan DWM, datang ke pabrik dan menimbulkan kegaduhan. Tn. Subiakto mengintrogasi hampir seluruh karyawan terkait pesanan cukup besar milik pelanggan 41427 yang terlambat selama hampir 7 minggu. Direktur perusahaan pemesan menelpon Tn. Subiakto sebelumnya dan menanyakan keterlambatan tersebut . Pesanan 41427 tidak dapat diselesaikan karena permasalahan operasional perusahaan yang kacau. Salah satu bagian untuk perakitan pesanan 41427 hilang dan terdapat mesin yang trouble sehingga pesanan tersebut tidak dapat dirakit dan otomatis tidak dapat dikirimkan. Mengetahui hal tersebut Tn. Subiakto berteriak memaksa seluruh karyawan untuk

\footnotetext{
${ }^{1}$ Corresponding Author: Jurusan Akuntansi, Fakultas Ekonomi dan Bisnis Universitas Jember, Jl. Kalimantan No. 37 Jember 68121
} 
menyelesaikan pesanan tersebut, apapun alasannya serta mengancam untuk memecat mereka. Hal tersebut membuat kepala mekanik marah dan menyatakan berhenti. Suasana pabrik pun bertambah kacau dan menimbulkan keresahan pada para karyawan.

Dino Roman, manajer pabrik, meminta Tn. Subiakto untuk berbicara di dalam kantornya. Tn. Subiakto pun meluapkan kemarahannya pada Dino Roman yang dianggapnya tidak mampu memperbaiki kinerja pabrik setelah 6 bulan kedatangannya dari pusat untuk mengambil alih pimpinan pabrik. Kegagalan pabrik tersebut dalam beroperasi mengakibatkan kerugian besar bagi Perusahaan DWM. Akhirnya Tn. Subiakto pun memberi waktu kepada Dino Roman untuk memperbaiki kondisi pabrik selama 3 bulan ke depan, apabila masih gagal, Tn. Subiakto akan merekomendasikan penutupan pabrik pada komite manajemen.

Dino Roman pun berusaha menyelesaikan pesanan 41427 malam ini juga sesuai dengan perintah Tn. Subiakto, namun terkendala oleh mesin NCX-10 yang trouble serta kepala mekanik yang berhenti. Dino Roman dan Mukhlas Ade, manajer produksi, sekuat tenaga mengerahkan semua karyawannya untuk fokus menyelesaikan pesanan tersebut. Hal tersebut menyebabkan Dino Roman melembur di pabrik sehingga harus membatalkan acara makan malam di luar bersama Chesyl, istrinya. Hal tersebut sangat mengecewakan istrinya, yang sebelumnya sudah merasa tertekan dan tidak tahan tinggal di kota kecil Tanggul. Kota Tanggul merupakan sebuah kota industri tua di pinggiran Kabupaten Jember dengan banyak pabrik-pabrik tua yang mulai ditinggalkan investornya. Tanggul merupakan kora kelahiran Dino Roman, sehingga Dino Roman menyetujui saat diminta mutasi ke kota ini 6 bulan yang lalu.

Dino Roman dan Mukhlas Ade pun akhirnya berhasil menyelesaikan dan mengirimkan pesanan 41427 walaupun harus mengerahkan seluruh karyawan untuk lembur, yang bertentangan dengan aturan perusahaan. Perusahaan sebelumnya telah memberikan peraturan menghapus kegiatan lembur karyawan. Hal ini tentu saja berakibat efisiensi yang buruk pada perusahaan dan Dino Roman harus memikirkan bagaimana membayar upah lembur karyawan diakibatkan pengerjaan pesanan 41427 .

\section{MONOLOG}

Dino Roman pun mulai memikirkan bagaimana solusi untuk memperbaiki kinerja pabrik dalam waktu 3 bulan. Dino Roman berusaha mencari-cari apa yang salah dalam pabriknya. Mereka memiliki karyawan yang cukup, robot, mesin-mesin, sumber daya didukung oleh sistem komputer dan teknologi. Salah satu permasalahan yang ditemukan Dino Roman adalah kompetisi bisnis dengan pesaing dari perusahaan Jepang. 3 tahun yang lalu, mereka masuk pasar dengan kualitas dan desain produk tinggi. Setelah saat ini pabrik Dino Roman mampu menyamai kualitas produk, perusahaan Jepang tersebut „,memukul ${ }^{\text {ee }}$ mereka dengan harga dan pengiriman.Dino Roman berpikir keras bagaimanakah cara untuk dapat menyamai mereka, karena ia merasa telah melakukan efisiensi dengan cukup baik .

Keesokan harinya, Dino Roman berangkat pagi-pagi sekali karena harus menghadiri meeting pimpinan di kantor pusat. Tn. Subiakto tidak memberi tahukan tema materi rapat kali ini. Dia hanya menginstruksikan untuk membawa data laporan yg lengkap bagi tiap-tiap bagian departemen operasional. Menurut rumor yang terdengar, Tn. Subiakto akan membeberkan betapa buruknya kinerja dari tiap-tiap bagian operasional. Tn. Subiakto akan menyerukan kepada para manajer untuk mencari inovasi cara-cara baru serta memberikan target pada setiap perencanaan. Tn. 
Subiakto juga menuntut setiap orang untuk tetap berkomitmen dan disiplin.

Tn. Subiakto adalah seorang Vice President yang selalu berusaha untuk menjadi pimpinan yang memiliki gagasan cemerlang. Tn. Subiakto pernah memiliki ide untuk mendirikan physical fitnees center untuk pekerjanya yang bermasalah dengan alasan kesehatan. Ia selau berusaha membawa kebahagiaan untuk pegawainya sehingga bisa bekerja lebih baik. Tn. Subiakto jugalah yang memberikan harapan pada Dino Roman akan masa depannya dengan perusahaan DWM, dengan promosi dari pegawai biasa hingga menjadi kepala bagian.

Sesampainya di Gedung DWM, Dino Roman bertemu dengan Leonita, salah seorang manajer divisi juga. Leonita mengatakan dengan berbisisk-bisik bahwa semua divisi mengalami kemacetan. Tn. Subiakto sedang berusaha keras meningkatkan performance penjualan semua divisi hingga akhir tahun ini.

Meeting dihadiri sekitar 20 orang yang serius menatap ke arah Tn. Subiakto, yang tengah memberikan pidato. Tn. Subiakto mengatakan terkait pentingnya mengurangi resiko serta mempunyai strategi pemasaran yang dapat diterima pasar tanpa mengurangi biaya-biaya yang strategis sehingga mampu meningkatkan jumlah produk di setiap lokasi. Tn. Subiakto juga mengemukakan bahwa penjualan semester pertama turun $20 \%$ dibandingkan tahun lalu. Total pembiayaan secara kasar meningkat. Bila dihitung perbandingan jam kerja yang diterapkan dengan standart, maka perusahaan kehilangan 12\% dari waktu efisiensi. Oleh karenanya, Tn. Subiakto menekankan bahwa masa depan bisnis perusahaan sangat tergantung kemampuan meningkatkan produktivitas.

\section{DIALOG}

Di tengah meeting, saat Dino Roman merogoh pena di sakunya untuk mencatat, ia malah mengeluarkan cerutu. Dino Roman tidak merokok lagi sehingga ia bertanya-tanya dari mana asal cerutu tersebut. Kemudian ia pun teringat, dua minggu lalu di bandara saat menghadiri meeting tahunan tentang kemampuan kinerja robotik, ia bertemu teman lamanya, Agil Sahir. Agil Sahir adalah seorang fisikawan. Mereka pun akhirnya terlibat suatu diskusi. Dino Roman pun menceritakan kemampuan robotics sebagai solusi untuk krisis productivitas di Amerika tahun 80an. Dino Roman pun mendapat promosi pada perusahaan DWM karena kemampuannya di bidang robotic.

Menurut Dino Roman, Robotic mampu meningkatkan productivitas sebesar $36 \%$. Namun dengan adanya robot tersebut perusahaan juga tidak sembarangan memberhentikan pegawainya. Perusahaan akan memindahkan tenaga kerja ke bagian yang memang membutuhkan. Jadi efisiensi dari perusahaan akan meningkat dan pengeluaran biaya menurun. Perusahaan akan dapat menjaga produknya seefisien mungkin dan mengatur keuntungan sebaik mungkin.

Agil Sahir kemudian menanyakan mengapa Dino Roman begitu yakin bila robotnya bisa meningkatkan kinerja setinggi mungkin. Dino Roman pun menjawab bahwa robot mampu meningkatkan produktivitas, karena menurut perhitungan dari perusahaan, penghargaan atahu nilai dari pekerja dan robot adalah sama. Agil Sahir pun menyanggah pendapat Dino Roman dengan mengatakan bahwa yang perusahaan gambarkan tersebut bukan productivitas yang sebenarnya. Kemudian Agil Sahir meminta kepada Dino Roman untuk dapat mendefinisikan berdasar pemikiran dan pengalaman Dino Roman mengenai definisi produktivitas. 


\section{Produktivitas}

"Produktivitas kerja berkaitan erat dengan pekerjaan seseorang." (Setiyanto \& Natalia, 2017)

"Secara operasional, itu adalah hubungan antara jumlah output (yaitu, produk yang diproduksi dengan benar yang memenuhi spesifikasi mereka) dan jumlah input (yaitu, semua jenis sumber daya yang dikonsumsi dalam proses transformasi)" (Goshu, Matebu, \& Kitaw, 2017)

"Sederhananya, produktivitas adalah efisiensi dalam produksi: berapa banyak output yang diperoleh dari serangkaian input yang diberikan. Dengan demikian, biasanya dinyatakan sebagai rasio input-output. Ukuran produktivitas faktor tunggal mencerminkan unit output yang diproduksi per unit." (Syverson, 2011)

Menurut Dino Roman, productivitas adalah usaha untuk memenuhi apa yang dibutuhkan dalam mencapai goal. Agil Sahir pun menambahkan bahwa setiap usaha yang mendekatkan perusahaan kepada goalnya bisa disebut produktivitas. Produktivitas tidak akan berarti jika Dino Roman tidak tahu apa yang menjadi goalnya. Dino Roman pun kembali menjawab bahwa goal perusahaan adalah meningkatkan efisiensi. Agil Sahir pun menyanggah jawaban Dino Roman dan mengatakan bahwa masalah utama Dino Roman adalah ia tidak mengetahui apa yang menjadi goal-nya. Menurut Agil Sahir, Dino Roman tidak akan pernah mengetahui arti produktivitas kecuali Dino Roman telah memahami tentang apa itu goal hingga saat Dino Roman telah mengetahuinya, maka selanjutnya ia hanya akan bermain dengan bilangan dan kata-kata. Sebelum berpisah, Agil Sahir pun meminta Dino Roman untuk berpikir apa yang menjadi goal perusahaan yang sebenarnya.

Selama di ruang meeting, Dino Roman mencoba memikirkan apa yang Agil Sahir katakan. Dino Roman merasa bahwa tak satu pun dari peserta yang mengikuti rapat di sini yang menanyakan sesuatu yang mendasar. Tn. Subiakto menjelaskan peluang biaya dan target 'produktivitas' dan sebagainya. Apakah ada yang benar-benar mengerti apa yang mereka lakukan?

Saat tiba waktu istirahat Dino Roman pun memutuskan untuk meninggalkan ruang meeting karena ia berpikir hanya membuang waktu mengikuti meeting sementara ia sendiri tidak tahu apa itu produktivitas. Meskipun sempat terlintas dalam pikirannya bahwa ada risiko Tn. Subiakto memecatnya, namun Dino Roman tetap memantapkan diri meninggalkan ruang meeting dengan menitipkan pesan Ahmadur Rosik, sesama manajer, bahwa ia harus kembali ke pabrik.

Dino Roman mengendarai mobilnya menuju pabrik. Namun sampai di perbukitan, ia berhenti dan duduk di lapangan. Ia berpikir mengenai pembicaraannya dengan Agil Sahir 2 pekan lalu. Setelah berpikir panjang, akhirnya Dino Roman menemukan jwabannya. Tujuan dari organisasi manufaktur adalah untuk menghasilkan uang.

\section{Tujuan Perusahaan}

"Tujuan dapat didefinisikan sebagai objek atahu tujuan suatu tindakan. Tujuan menentukan hasil yang diinginkan atahu kinerja yang harus direalisasikan, sedangkan kinerja mengacu pada apa yang 
sebenarnya dicapai" (van der Hoek, Groeneveld, \& Kuipers, 2018).

"Parameter perencanaan strategis yang berarti bahwa menyelaraskan tujuan manajer dengan karyawan untuk mencapai tujuan yang diperkenalkan oleh organisasi" (Islami, Mulolli, \& Mustafa, 2018).

Jika tujuan perusahaan adalah untuk membuat uang, maka untuk tahun terakhir atahu lebih, pabrik telah bergerak jauh dari tujuannya. Jadi untuk menyelamatkan pabrik, Dino Roman harus membuatnya produktif, ia harus membuat pabrik menghasilkan uang untuk perusahaan DWM.

Dino Roman sampai di pabrik pada sore hari, namun Dino Roman sebelum memasuki kantor, Dino Roman memutuskan untuk mengambil jalan memutar melalui pabrik. Ia ingin mendapat pandangan segar. Dino Roman mengelilingi pabrik dan masuk pada salah satu area kerja. Dino Roman kebetulan mendapati tiga orang pekerja duduk-duduk santai di bangku. Mereka berbagi koran, membaca dan berbicara satu sama lain. Mereka melihat Dino Roman dan langsung bergegas pergi dalam tiga arah yang terpisah.

Hal ini membuat Dino Roman marah, terlebih mengingat bahwa pabrik ini berada dalam kesulitan. Dino Roman sebelumnya berpikir semua karyawan akan mencoba untuk bekerja lebih keras untuk menyelamatkan tempat ini. Namun ia mendapati tiga orang karyawannya sedang bersantai. Dino Roman pun mendatangi supervisor mereka untuk menanyakan masalah tersebut. Supervisor memberikan beberapa alasan tentang bagaimana para karyawan sebagian besar terjebak pada kuota mereka dan mereka sedang menunggu bagian lain. Dino Roman pun memerintahkan supervisor untuk mencari apapun pekerjaan untuk dilakukan bagi tiga orang tersebut.

Terlintas di pikiran Dino Roman, apakah dengan berasumsi bahwa membuat orang bekerja dan menghasilkan uang adalah hal yang sama? Selama ini mereka cenderung melakukan asumsi tersebut di masa lalu. Aturan dasar telah dan terus membuat semua orang dan segala sesuatu di sini bekerja sepanjang waktu, terus mendorong produk keluar pintu. Dino Roman memandang sekeliling dan melihat kebanyakan orang bekerja hampir sepanjang waktu. Namun tidak menghasilkan uang.

Sesampainya di ruang kantornya, Dino Roman duduk di kursi dan terus berpikir tentang pengukuran, tentang semua cara yang digunakan untuk mengevaluasi kinerja, jadwal pertemuan dan tanggal jatuh tempo, persediaan, total penjualan, total biaya. Ia bertanya dalam hati apakah ada cara sederhana untuk mengetahui apakah kita menghasilkan uang?

Vista seorang kontroler pabrik menemui Dino Roman. Vista adalah pegawai senior yang telah bekerja di pabrik selama 20 tahun lebih dan dua tahun lagi akan pensiun. Vista merupakan akuntan terbaik yang pernah dimiliki pabrik. Dino Roman memutuskan untuk berdiskusi dengan Vista. Dino Roman mencoba memberikan pertanyaan pada Vista, apakah benar tujuan perusahaan ini adalah untuk menghasilkan uang? Vista pun tertawa dan membenarkan. Dino Roman kembali bertanya Bagaimana cara untuk mengetahui bahwa kita membuat uang?

Vista mengatakan bahwa Dino Roman harus memiliki beberapa jenis pengukuran seperti laba bersih dan laba atas investasi (ROI). Vista juga mengingatkan bahwa tetap ada kemungkinan perusahaan yang menunjukkan laba bersih dan ROI yang baik, jatuh bangkrut jika kehabisan uang tunai. Oleh karenanya, Arus kas yang buruk adalah apa yang membunuh sebagian besar bisnis yang merosot. Oleh karenanya 
perhitungan cash flow diperlukan sebagai pengukuran ketiga.

Setelah Vista pergi, Dino Roman mencoba memikirkan ketiga pengukuran untuk mengetahui apakah perusahaan membuat uang: laba bersih, ROI dan arus kas. Dino Roman mencoba mencari tahu jika ada salah satu dari tiga pengukuran yang lebih diutamakan dengan mengorbankan dua lainnya dan memungkinkan Dino Roman mengejar tujuan. Berdasarkan pengalaman, Dino Roman tahu ada banyak permainan orang-orang di atas dimana mereka membuat organisasi memberikan laba bersih yang lebih besar tahun ini dengan mengorbankan laba bersih di tahun-tahun mendatang. Mereka dapat membuat banyak keputusan yang tidak berisiko dan memiliki salah satu pengukuran yang terlihat tampak hebat sementara yang lain ditangguhkan. Selain itu, rasio antara tiga pengukuran mungkin bervariasi sesuai dengan kebutuhan bisnis.

Untuk membuat uang yaitu dengan cara meningkatkan laba bersih, sementara secara bersamaan meningkatkan laba atas investasi, dan secara simultan meningkatkan arus kas. Dino Roman berpikir bahwa selama ini ia telah bekerja di luar tiga pengukuran tersebut dalam mengevaluasi kemajuan ke arah tujuan. Dan akhirnya Dino Roman telah sampai pada kesimpulan bahwa kenaikan simultan di semua tiga pengukuran adalah apa yang seharusnya diusahakan untuk dicapai. Namun pertanyaan selanjutnya adalah bagaimanakah membangun hubungan langsung antara tiga pengukuran dan apa yang terjadi di pabrik? Jika Dino Roman dapat menemukan beberapa hubungan logis antara operasi sehari-hari dan kinerja perusahaan secara keseluruhan maka Dino Roman akan memiliki dasar untuk mengetahui apakah ada sesuatu yang produktif atahu tidak produktif bergerak ke arah tujuan atahu jauh dari itu.

Esok harinya, Dino Roman memutuskan untuk menemui Agil Sahir untuk meminta pertolongannya menjawab permasalahan pabrik yang sedang dihadapinya. Setelah mendapatkan nomer telpon Agil Sahir dari buku lamanya, Dino Roman segera menelpon Agil Sahir. Agil Sahir ada di London. Dino Roman pun mengingatkan Agil Sahir tentang perbincangan mereka di Bandara dua pekan lalu. Dino Roman pun dengan ragu berkata bahwa tujuan dari perusahaan manufaktur adalah untuk menghasilkan uang. Tetapi Agil Sahir tidak menertawakannya, bahkan membenarkan Dino Roman.

Dino Roman pun kemudian menayakan perihal pengukuran untuk membantu perusahaan menghasilkan uang. Pengukuran laba bersih, return pada investasi dan cash flow, digunakan oleh level eksekutif perusahaan untuk mengecek arah proses menuju tujuan keseluruhan perusahaan. Namun di level bawah, seperti pada pabrik Dino Roman, ukuran itu tidak memberikan banyak makna. Jadi Dino Roman menayakan pada Agil Sahir bagaimana ia dapat tahu apa yang terjadi dalam pabrik adalah benar benar produktif apa tidak?

\section{Throughput}

"Throughput didefinisikan sebagai tingkat di mana suatu sistem menghasilkan uang, yaitu, jumlah produk atahu layanan yang dapat diproduksi dan dijual perusahaan dalam periode tertentu. Ini dihitung dengan mengurangi bahan langsung dari pendapatan penjualan" (Lutilsky, Liovic, \& Markovic, 2018).

Agil Sahir pun kemudian memberikan saran kepada Dino Roman terkait seperangkat pengukuran yang berbeda yang telah ia kembangkan, yaitu ukuran yang 
menunjukkan tujuan untuk menghasilkan uang yang banyak, tapi juga yang menyediakan peraturan operasional dalam menjalankannya, antara lain:

1. Throughput, yaitu tingkat dimana sistem menghasilkan uang melalui penjualan. Through penjualan bukan produksi. Jika kita memproduksi sesuatu, tetapi tidak menjualnya, itu bukan throughput.

2. Inventory, yaitu keseluruhan uang yang sistem telah investasikan dalam membeli sesuatu untuk kemudian dijual.

3. Operational Expenses, yaitu keseluruhan uang yang sistem keluarkan dengan tujuan mengubah persediaan ke throughput.

Agil Sahir memutuskan untuk mendifinisikan hal tersebut karena yakin akan lebih baik dengan tidak mengambil nilai tambah ke dalam akun. Hal tersebut menghilangkan keraguan tentang apakah menghabiskan dolar merupakan investasi atahu biaya.

Setelah pembicaraannya dengan Agil Sahir, Dino Roman mendapat kabar bahwa kepala perusahaan ingin datang untuk kesempatan foto dengan salah satu robot Dino Roman. Hal ini membuat Dino Roman memikirkan efisiensi robot ini. Keesokan paginya, Dino Roman pergi untuk bekerja lembur dan langsung menuju ke kantor Vista untuk membahas tentang angka- angka baru yang diberikan oleh Agil Sahir. Mereka kemudian mengajak manajer persediaaan Ulfah dan Mukhlas, supervisor di pabrik, untuk membahas lebih lanjut tentang angka-angka tersebut. Mereka mencari tahu beberapa hal yang salah terkait tujuan dan kemudian Dino Roman memutuskan untuk membahas apa yang telah ia bicarakan dengan Agil Sahir sebelumnya.

Dino Roman dan tim-nya pun menemukan bahwa robot meningkatkan biaya, biaya operasional, dan karena itu kurang produktif. Menerapkan robot meningkatkan biaya dengan tidak mengurangi yang lain, seperti tenaga kerja langsung. Tenaga kerja itu bergeser ke bagian lain pada pabrik.

Setelah menjelaskan semuanya, Dino Roman dan timnya (Mukhlas dari produksi, Vista dari akuntansi dan Ulfah dari pengendali persediaan) disepakati arti throughput, persediaan dan biaya operasional.

Vista, menyatakan hubungan sebagai berikut. "Throughput adalah uang yang masuk. Persediaan adalah uang yang saat ini berada dalam sistem. Dan biaya operasional adalah uang dimana kita harus membayar untuk membuat throughput terjadi" Mukhlas skeptis bahwa segala sesuatu dapat dipertanggungjawabkan dengan tiga pengukuran. Vista menjelaskan bahwa peralatan, mesin, bangunan, seluruh pabrik semua adalah persediaan. Seluruh pabrik merupakan investasi yang bisa dijual.

Ulfah pun mengatakan bahwa investasi adalah hal yang sama sebagai persediaan. Kemudian mereka memutuskan bahwa sesuatu yang drastis perlu dilakukan dengan mesin. Tapi bagaimana mereka bisa melakukan itu tanpa menurunkan efisiensi? Dino Roman menelpon Agil Sahir dan seketika itu juga ia memutuskan malam ini akan berangkat menemui Agil Sahir di New York.

Tak beberapa lama kemudian Agil Sahir datang dan langsung mengajak Dino Roman untuk sarapan di restoran. Mereka pun kembali terlibat diskusi. Agil Sahir pun mengatakan perlunya mencapai keseimbangan pabrik, dimana tiap-tiap kapasitas dan sumber daya diseimbangkan dengan permintaan dari pasar. Tujuannya bukan untuk meningkatkan satu pengukuran, namun mengurangi beban operasional dan mengurangi persediaan sekaligus meningkatkan throughput. Terdapat bukti matematis yang dapat dengan jelas menunjukkan bahwa ketika kapasitas dipangkas sesuai tuntutan permintaan, tidak lebih dan tidak kurang, throughput turun, sementara 
persediaan melewati batas atas. Dan karena persediaan naik, biaya operasional juga naik. Hal ini disebabkan kombinasi dari dua fenomena yang ditemukan di setiap pabrik, yaitu:

1. Peristiwa dependen, yaitu bahwa suatu peristiwa, atahu serangkaian peristiwa, harus dilakukan sebelum yang lain dapat dimulai (kegiatan berikutnya tergantung pada orang-orang sebelum itu)

2. Fluktuasi statistik, yaitu beberapa jenis informasi dapat ditentukan secara tepat. Sebagai contoh, jika kita perlu mengetahui kapasitas tempat duduk di restoran ini, kita dapat menentukan dengan tepat dengan cara menghitung jumlah kursi di setiap meja. Tapi ada jenis lain dari informasi yang tidak bisa diprediksi secara tepat. Seperti berapa lama waktu yang dibutuhkan pelayan untuk melayani pelanggan. Atahu berapa banyak telur di dapur yang akan diperlukan hari ini. Jenis informasi bervariasi dari satu ke yang lainnya. Mereka tunduk pada fluktuasi statistik.

Sebelum meninggalkan restoran untuk janji pertemuan lainnya, Agil Sahir meminta Dino Roman untuk memikirkan pengaruh kombinasi fenomena dua hal tersebut terhadap pabrik.

Dino Roman mulai bekerja kembali pada Senin pagi dan mengetahui bahwa Ahmadur Rosik telah meninggalkan pesan. Dia membutuhkan 100 bagian malam ini, namun Dino Roman ragu apakah ia bisa melakukannya. Kemudian Dino Roman mengumpulkan seluruh karyawannya dan mulai berbicara tentang apa yang telah ia pelajari selama perjalanan mendaki bersama kelompok Pramuka putanya kemarin. Para karyawan tampak tidak tertarik. mereka ragu-ragu terhadap cara baru Dino Roman. Tapi Dino Roman akhirnya membuktikan sendiri cara barunya dalam memproses pesanan Ahmadur. Akhirnya para karyawan menjadi sangat tertarik, bahkan pengawas produksi pun sekarang menjadi sangat menyetujui cara Dino Roman.

\section{Bottleneck}

"Bottleneck adalah operasi yang tidak memiliki kapasitas yang cukup untuk mengimbangi tingkat throughput yang diinginkan. Untuk alasan ini, bottleneck umumnya memiliki banyak persediaan work-in-process yang menumpuk di depannya, dan operasi hilir umumnya kekurangan komponen yang dihasilkan oleh operasi bottleneck" (Pegels \& Watrous, 2005)

"Bottleneck didefinisikan sebagai masalah yang terjadi di stasiun kerja yang membatasi efisiensi seluruh proses. Ini dapat menyebabkan situasi di mana stasiun kerja sebelum bottleneck dapat menyelesaikan pemrosesan sehingga tidak dapat melanjutkan material, karena pekerjaan yang mengikutinya masih terlibat dalam pemrosesan sebelumnya” (Sari, Syahputri, Rizkya, \& Siboro, 2019)

"Bottleneck umumnya diakui sebagai beberapa sumber daya atahu utilitas, yang sangat membatasi kinerja sistem produksi" (Wang, Zhao, \& Zheng, 2005)

Keesokan harinya, semua karyawan sudah siap di pabrik untuk membahas langkah selanjutnya. Namun mereka semua bingung bagaimana melanjutkan proses berikutnya. Akhirnya Dino Roman menghubungi Agil Sahir untuk mendiskusikan hal 
tersebut. Agil Sahir kemudian memperkenalkan Dino Roman dengan konsep bottleneck (hambatan) dan non- bottleneck (bukan hambatan). Agil Sahir mendefinisikan bottleneck sebagai sumber daya apapun yang memiliki kapasitas sama dengan atahu kurang dari permintaan yang diletakkan di atasnya. Sedangkan nonbottleneck adalah sumber daya apapun yang memiliki kapasitas lebih besar dari permintaan yang diletakkan di atasnya. Agil Sahir menjelaskan bahwa Dino Roman tidak harus mencoba untuk menyeimbangkan kapasitas dengan permintaan, melainkan menyeimbangkan aliran produk melalui pabrik. Seperti sebelumnya, percakapan dengan Agil Sahir pun berakhir dengan cepat. Maka Dino Roman dan timnya mulai mencari-cari apa yang menjadi bottleneck dalam pabrik mereka.

Kemudian, Dino Roman dan timnya mengenali bottleneck, area di mana kapasitas tidak sama dengan permintaan, seperti Nuril yang merupakan anak yang lambat pada saat mendaki. Bottleneck tersebut adalah mesin terbaru mereka NCX-10. Dengan penemuan ini, berjalanlah ide-ide yang berkaitan dengan reorganisasi pabrik seperti yang Dino Roman lakukan saat mendaki. Produksi adalah suatu proses dan tidak dapat dipindahkan dengan begitu mudah. Banyak proses bergantung pada tahap sebelumnya untuk dapat menyelesaikan tahap berikutnya. Dino Roman akan membutuhkan lebih banyak mesin, dimana menngambil lebih banyak modal, dan divisi tidak akan berjalan untuk itu.

Dino Roman menghubungi Agil Sahir kembali untuk mendiskusikan penemuan bottleneck di pabriknya dan Agil Sahir pun memutuskan untuk mengunjungi pabrik Dino Roman. Agil Sahir dan Dino Roman berkelililng pabrik dan melihat berbagai bottleneck operasional pabrik dalam memenuhi pesanan. Agil Sahir memberikan saran tentang bagaimana memperbaiki bottleneck untuk memenuhi permintaan. Agil Sahir mengatakan kepada Dino Roman bahwa pabrik tanpa hambatan (bottleneck) akan memiliki kelebihan kapasitas yang sangat besar. Setiap pabrik harus memiliki bottleneck. Pernyataan Agil Sahir ini membuat Dino Roman bingung, kemudian ia menanyakan kepada Agil Sahir, apakah yang dibutuhkan adalah untuk meningkatkan kapasitas pabrik? Jawabannya adalah kapasitas yang lebih pada bottleneck. Mesin lebih untuk melakukan operasi bottleneck mungkin membantu, tapi yang lebih penting adalah bagaimana membuat kesemuanya berjalan lebih efektif. Agil Sahir mengatakan bahwa mereka memiliki kapasitas yang tersembunyi karena beberapa pemikiran mereka yang keliru.

Beberapa cara untuk meningkatkan kapasitas pada bottleneck adalah dengan tidak memiliki down time dalam bottleneck, dan memastikan mereka hanya bekerja pada produk-produk berkualitas sehingga tidak membuang-buang waktu, dan meringankan beban kerja dengan menyerahkan beberapa pekerjaan kepada vendor. Agil Sahir kemudian menunjukkan kepada mereka bagaimana mereka salah menghitung biaya per bagian dari Bottleneck. Agil Sahir menanyakan berapa biaya (X dan heat treat) ketika mesin bottleneck turun. Vista mengatakan Rp. 320.000 per jam untuk mesin X dan Rp. 21 per jam untuk heat treat. Berapa banyak ketika seluruh pabrik down? Sekitar Rp. 16.000.000 juta. Berapa jam yang tersedia per bulan? Sekitar 585. Setelah perhitungan, Agil Sahir menjelaskan bahwa ketika Bottleneck down selama satu jam, biaya sebenarnya adalah sekitar Rp. 27.350.000, biaya seluruh sistem. Setiap menit downtime pada bottleneck itu berarti ribuan dolar dari kehilangan throughput, karena tanpa bagian dari bottleneck, pabrik tidak bisa menjual produk. Oleh karena itu, pabrik tidak dapat menghasilkan throughput.

Dino Roman dan tim melakukan meeting lagi keesokan harinya. Mereka 
berdiskusi tentang tindakan apa yang akan diambil pada bottleneck. Mereka memutuskan beberapa hal untuk mulai diterapkan di pabrik.

Dino Roman pun kemudian ke pabrik dan bertemu kembali dengan kelompok reguler. Para karyawan mengerjakan beberapa rincian untuk menjaga bottleneck terusmenerus sibuk. Dalam proses ini mereka menemukan bahwa mereka membutuhkan sistem lain untuk menginformasikan kepada para pekerja bahan apa yang memiliki prioritas pada non-bottleneck. Tag merah dan hijau adalah jawabannya. Mereka memutuskan untuk menerapkan sistem penandaan (tagging system) dimana akan membiarkan karyawan dengan bagian yang memiliki prioritas. Merah untuk bagian bottleneck yang akan bekerja pertama karena tidak menahan mesin bottleneck, dan hijau untuk bagian-bagian non-bottleneck.

Dino Roman kembali bekerja untuk mengetahui bahwa rencana mereka perlahan- lahan meningkatkan produksi. Dua belas pesanan telah dikirimkan. Dino Roman merasa senang. Namun, hal itu tidak cukup sehingga ia meminta saran lebih pada meeting hari Rabu. Pada hari Rabu, Mukhlas muncul ke pabrik dengan mesin tua yang digunakan untuk melakukan apa yang NCX-10 lakukan untuk mengambil beberapa kelebihan beban pekerjaan. Mesin tua tersebut berfungsi untuk melengkapi bottlenecks.

Setelah acara kencan di hari sabtu, hubungan Dino Roman dan istrinya pun mulai membaik. Pabrik pun juga menjadi lebih dan lebih efisien. Mereka terus menerapkan solusi baru yang meningkatkan produktivitas pabrik. tetapi timbul jeda waktu (lag time) dengan dua bottlenecks karena pekerja dipinjamkan ke area lain dan tidak berada pada bottlenecks ketika diperlukan untuk memproses pesanan lain. Tampaknya tidak ada yang harus dilakukan sambil menunggu mesin bottleneck untuk menyelesaikan batch. Oleh karena itu, sesuai dengan gagasan bahwa semua orang perlu untuk tetap sibuk, pekerja berada di area lain di antara jeda batch. Dino Roman memutuskan untuk menempatkan mandor di setiap lokasi sepanjang waktu. Kemudian salah satu dari mandor, yaitu mandor shift malam, menemukan cara untuk memproses lebih banyak bagian dengan mencampur dan mencocokkan pesanan berdasarkan prioritas, meningkatkan efisiensi sebesar sepuluh persen. Akhirnya, satu proses yang dikirim melalui bottleneck dapat dicapai melalui cara lain yang lebih tua dan karena itu membebaskan waktu bagi bottleneck.

Tim Dino Roman memutuskan untuk membuat perayaan karena rekor baru yang mereka telah buat dalam pengiriman pesanan pada bulan ini. Mereka pergi keluar dan Ulfah menantarkan Dino Roman yang sedang mabuk pulang ke rumah. Chesyl pun menjadi curiga dan berpikir bahwa Dino Roman memiliki hubungan khusus dengan Ulfah. Hubungan Chesyl dan Dino Roman pun memburuk kembali.

Keesokan harinya di pabrik Dino Roman mendapat informasi bahwa bottleneck baru terbentuk di seluruh pabrik. Sistem prioritas baru yang ditempatkan untuk semua bagian melalui bottlenecks menyebabkan persediaan menurun. Itu hal yang baik bukan? Namun persediaan yang lebih rendah mengungkapkan lebih banyak bottlenecks. Dino Roman pun menghubungi Agil Sahir untuk mendapatkan saran lagi. Agil Sahir pun mengatakan ia butuh untuk melihat kondisi pabrik lagi.

Dino Roman menjemput Agil Sahir di Airport dan menanyakan berbagai persoalan yang dialami pabrik terkait bottleneck. Dino Roman dan timnya menduga bahwa ada bottleneck lain terbentuk di pabrik, namun Agil Sahir berpikir sebaliknya. Agil Sahir menjelaskan bagaimana bottlenecks "memakan" non-bottleneck dan sebaliknya dan itulah letak masalah mereka di pabrik. Agil Sahir menegaskan bahwa 
tidak adan bottleneck baru. Apa yang sebenarnya terjadi adalah hasil dari beberapa pemikiran lama. Mempekerjakan non-bottleneck pada kapasitas maksimum pada bagian bottleneck telah menyebabkan masalah tersebut. Semua bagian ditumpuk di depan bottleneck dan yang lainnya menunggu bagian non-bottleneck untuk perakitan akhir. Perlu ada keseimbangan. Tag merah dan hijau perlu dimodifikasi. Tampaknya seolah-olah bottleneck akan mengontrol aliran, dengan hanya mengirimkan secara tepat apa yang mereka butuhkan dan kapan mereka membutuhkannya.

Di rumah, Dino Roman berpikir tentang bagaimana menerapkan apa yang telah ia pelajari dari Agil Sahir. Anak-anaknya bertanya apakah mereka bisa membantu dan mereka mengatakan bahwa merekasebenarnya lebih dari yang mereka pikirkan. Dino Roman pun sedikit terhibur dengan ucapan anak-anaknya.

Keesokan harinya, Dino Roman dan Tim bertemu dengan Agil Sahir dan menyusun jadwal baru yang akan memprediksi kapan barang akan selesai dan kapan beberapa barang perlu dirilis. Ralf, yang ahli komputer, mengatakan dia dapat menyusun jadwal untuk bagian bottleneck dan ketika mereka harus dibebaskan. Ini akan meringankan setiap kelebihan persediaan di depan bottlenecks, tapi ia pun bingung bagaimana dengan non-bottleneck? Agil Sahir menjawab bahwa dengan data yang sama dari bottleneck untuk perakitan akhir, Dino Roman dan tim harus dapat memprediksi bagian non-bottleneck dengan baik juga. Ini akan membuat beberapa waktu, tetapi ada cukup bagian di depan bottleneck untuk tetap sibuk selama satu bulan. Setelah meeting usai, Dino Roman mengantarkan Agil Sahir kembali ke bandara.

Dino Roman menghadiri meeting dengan Tn. Subiakto dan manajer lainnya dari DWM. Dalam meeting tersebut, mereka mengatakan bahwa divisinya adalah satusatunya yang menghasilkan keuntungan sekarang. Namun Tn. Subiakto tidak memuji Dino Roman seperti Dino Roman pikir seharusnya. Dino Roman memutuskan untuk berbicara dengan Tn. Subiakto secara pribadi. Tn. Subiakto setuju untuk menjaga pabrik tetap beroperasi dan tidak akan menutupnya jika Dino Roman mampu memberinya peningkatan bottom line (laba) lebih dari 15\% bulan depan. Itu akan sulit karena sangat bergantung pada permintaan dari pasar.

Setibanya di rumah, Dino Roman memikirkan tentang $15 \%$ peningkatan laba yang disyaratkan Tn. Subiakto. Beberapa saat kemudian telpon berdering. Ternyata telpon dari Agil Sahir yang mengatakan bahwa ia tidak akan dapat berbicara dengan Dino Roman selama beberapa minggu ke depan sehingga ia perlu berbicara dengannya sekarang. Dino Roman segera menginformasikan pada Agil Sahir masalah baru terkait persediaan yang lebih dan kurangnya troughput.

Agil Sahir menyarankan Dino Roman untuk memotong ukuran batch menjadi setengah. Tentu saja, hal ini akan menyebabkan perlunya melakukan beberapa hal dengan vendor, tetapi jika hal tersebut dapat dilakukan, hampir semua biaya dapat dipotong setengah. Mereka juga mendapatkan waktu respon lebih cepat dan mengurangi lead time untuk pesanan. Kedengarannya cukup bagus. Dino Roman kemudian mengadakan pertemuan dengan Johnny Johns yang mengatakan kepadanya betapa cepat ia dapat menghasilkan produk dan ia membutuhkan lebih banyak kontrak.

Tn. Subiakto bangun di tengah malam karena bermimpi buruk. Semua yang dapat ia pikirkan adalah tentang pabrik dan bagaimana angka-angka terlihat seperti biaya yang terus meningkat ketika sebenarnya mereka melakukan sebaliknya.

Vista datang ke kantor keesokan harinya dan mengatakan ia bisa memecahkan masalah biaya untuk beberapa bulan, tapi solusi ini tidak sah menurut departemen 
akuntansi sehingga akan sangat beresiko.

Bayu menelpon kembali dengan tawaran pesanan 1000 Model selama 2 minggu. Dengan tawaran dari Bayu ini, mereka akan dapat meningkatkan penjualan, saat ini dan masa mendatang. tapi Dino Roman teringat saran Agil Sahir untuk mengurangi batch. Dino Roman pun mengatakan pada Bayu bahwa hal tersebut tidak mungkin, mereka hanya bisa melakukan 250 model per seminggu selama 4 minggu. Akhirnya mereka mendapatkan pesanan tersebut dan pelanggan sangat puas dengan hasilnya.

Pada awal bulan baru, Dino Roman dan tim mengadakan meeting dan Vista datang dengan laporan yang menyatakan bahwa mereka telah memukul batas $15 \%$ plus tambahan sedikit, yaitu sebesar $17 \%$. Itu bagus, tapi itu tidak berasal dari model akuntansi biaya yang lama. Dino Roman pergi selama dua hari dan datang kembali ke pabrik. Saat itu sedang ada shooting program TV tentang robot mereka. Dino Roman tidak sengaja tergelincir berbicara tentang ukuran batch baru dan angka ke Ahmadur. Hal ini menyebabkan kantor pusat mengirimkan auditor untuk memeriksa pabrik Dino Roman. Auditor menemukan bahwa peningkatan hanya 12,8\%. Sebagian besar dari akun tersebut berasal dari pesanan baru.

Saat meeting untuk membahas penemuan auditor tersebut, sebuah helikopter mendarat di lapangan pabrik. Ternyata $\mathrm{Mr}$ Tn. Imam, pemilik perusahaan yang menempatkan pesanan pada pabrik Dino Roman, datang secara pribadi ke pabrik. Ia menyalami satu-persatu setiap orang dan mengucapkan selamat kepada semua orang karena ia akan memberikan kontrak pekerjaan yang besar pada mereka bukan lagi 1000 bagian tapi bagian.

Pertemuan di kantor pusat diadakan untuk menentukan apakah Pabrik Dino Roman akan ditutup atahu tidak. Dino Roman pikir dia akan bertemu dengan Tn. Subiakto dan eksekutif puncak lainnya. Sebaliknya, ia hanya bertemu dengan bawahan mereka. Dalam pertemuan tersebut, Ahmadur tidak mendengarkan apa yang Dino Roman katakan dan mengutuk pabriknya. Dino Roman mengusahakan harapan terakhirnya dan pergi ke kantor Tn. Subiakto mencoba untuk meyakinkannya.

Ternyata Tn. Subiakto telah memutuskan bahwa pabrik akan tetap beroperasi dan Dino Roman juga mendapatkan promosi ke posisi Tn. Subiakto saat ini. Sedangkan Tn. Subiakto juga bergerak ke posisi yang lebih tinggi. Sekarang Dino Roman harus mengelola tiga pabrik sebagai divisi keseluruhan. Ia menelpon Agil Sahir dengan putus asa dan meminta bantuan. Agil Sahir menunggu sampai ia memiliki pertanyaan spesifik.

Dino Roman kembali ke pabrik tuanya dengan posisi baru. Pertama-tama, Dino Roman berbicara dengan Vista, Mukhlas, Ulfah dan terakhir Ralph. Satu per satu, ia berikan promosi. Sekarang adalah waktu untuk membentuk tim Dino Roman untuk Divisi. Dia ingin menjadi manajer pabrik untuk melanjutkan upaya mereka. Segalanya secara total yang ditempatkan ke dalam pabrik diperlukan untuk divisi.

Dino Roman secara tegas mengambil alih divisi. Dengan saran dari istrinya, dia memutuskan untuk meminta bantuan timnya di pabrik. Setiap sore mereka akan bertemu untuk memecahkan masalah. Tim ini sekali lagi akan bersama-sama. Namun Kali ini berbeda karena sekarang mereka berbicara tentang bagaimana mereka akan mengambil tindakan terhadap seluruh divisi, bukan hanya satu pabrik. Setelah hari pertama itu nampak jelas, mereka semua akan saling membutuhkan.

Hari kedua mereka melanjutkan diskusi tentang tabel periodik dari sebuah elemen, dan bagaimana para ilmuwan salam sejarah, Mandala, sebenarnya mendapat 
meja apapun. Mungkin itu adalah bagaimana mereka akan memecahkan masalah besar divisi, dengan memahami bagaimana para ilmuwan mulai tanpa apa-apa dan mencapai pesanan. Sebuah cara untuk menentukan nasib mereka melalui pesanan yang intensif yang sangat diperlukan.

Tim bertemu sekali lagi mencoba untuk menempatkan apa yang mereka lakukan di pabrik dengan aturan yang dapat mereka ikuti. Mereka mengembangkan lima langkah proses evaluasi dan mengatasi masalah dalam divisi. Langkah pertama: mengidentifikasi sistem bottlenecks; Langkah kedua: memutuskan bagaimana memanfaatkan bottlenecks tersebut; Langkah ketiga: mengkoordinasi segala sesuatu untuk keputusan langkah kedua; Langkah keempat: mengevaluasi sistem bottleneck; Langkah kelima: jika dalam langkah sebelumnya bottleneck telah rusak, lanjutkan kembali ke langkah satu. Tampaknya begitu sederhana, hanya berbeda.

Beberapa hari kemudian, Tim memutuskan untuk merevisi dan mengembankan aturan yang telah dibuat sehingga siap untuk dilaksanakan, yaitu: Langkah pertama - mengidentifikasi sistem bottleneck; Langkah kedua - memutuskan bagaimana memanfaatkan sistem bottleneck; Langkah ketiga - mengkoordinir segala sesuatu yang lain untuk keputusan langkah kedua; Langkah keempat - mengevaluasi sistem bottleneck; Langkah peringatan kelima : Jika dalam langkah-langkah sebelumnya, hambatan telah rusak, kembali ke langkah pertama, tapi jangan membiarkan inersia menyebabkan kendala sistem. Hal ini juga telah menemukan bahwa mereka telah menggunakan bottlenecks untuk memproduksi pesanan fiktif dalam upaya untuk menjaga bottleneck sibuk. Itu akan membebaskan 20\% kapasitas, yang diterjemahkan ke dalam pangsa pasar.

Dino Roman mencoba berbicara dengan kepala penjualan, Johnny. Dino Roman menemukan bahwa ada market order untuk mengisi kapasitas. Ini ada di Eropa, dengan menjual harga yang lebih rendah namun tidak akan mempengaruhi klien domestik. Jika itu bisa dilakukan, akan membuka keseluruhan pasar baru. Kemudian Dino Roman merenungkan pertanyaan Agil Sahir, untuk menentukan teknik manajemen apa yang harus dimanfaatkan. Dino Roman menentukan bagaimana fisikawan mendekati masalah. Mungkin ini akan menyebabkannya memperoleh jawaban.

Dino Roman mengalami masalah di pabrik. Tampaknya semua pesanan baru telah menciptakan bottleneck baru. Setelah menganalisis masalah, mereka sepakat untuk meningkatkan persediaan di depan bottlenecks dan memberitahu sales untuk tidak menjanjikan pengiriman pengiriman baru selama empat minggu, dua kali lipat dari sebelumnya. Ini akan melukai hubungan baru antara penjualan dan produksi, tetapi diperlukan. Produksi adalah proses perbaikan yang berkelanjutan, dan ketika muncul masalah baru mereka harus ditangani dengan tepat.

Dino Roman mendapatkan telpon dari Tn. Subiakto untuk mendiskusikan tindakan barunya dan mendiskusikan fakta yang ia ketahui tentang pabrik Ahmadur yang kehilangan bottom line-nya (laba). Tn. Subiakto juga tidak dapat mengerti mengapa sistem Dino Roman dapat bekerja sehingga Tn. Subiakto akan datang menemui Dino Roman dan memintanya untuk mengajarkan tekniknya pada Tn. Subiakto.

Akhirnya, berjuang dengan jawaban atas pertanyaan Agil Sahir, Dino Roman datang dengan beberapa pertanyaan pada dirinya sendiri: Apa yang berubah? Apa yang harus berubah? Bagaimana menyebabkan perubahan? Menjawab pertanyaanpertanyaan ini adalah kunci manajemen, dan keterampilan yang dibutuhkan untuk 
menjawab mereka adalah kunci untuk menjadi manajer yang baik dan secara otomatis menjadi jawaban atas pertanyaan Agil Sahir.

\section{EPILOG}

"Peningkatan kinerja karyawan di masa depan yang mengarah pada peningkatan kinerja organisasi" (Noronha, Aquinas, \& Manezes, 2016)

"Meningkatkan kinerja di tingkat organisasi sangat kompleks, dan tidak ada jaminan bahwa peningkatan kinerja karyawan akan mengarah pada bottom-line perbaikan dalam hasil organisasi" (Dorsey \& Mueller-Hanson, 2017)

"Kinerja manajerial terkait dengan perbandingan tujuan dan sasaran yang telah ditentukan dengan yang sebenarnya output dari karyawan. Jika perusahaan mampu mencapai hasil yang diinginkan organisasi itu” (Qureshi \& Hassan, 2013)

Beberapa pelajaran penting yang Dino Roman dan timnya dapatkan dari semua yang telah terjadi di pabrik adalah:

1. Bahwa orang yang bekerja atahu mesin berjalan dan menghasilkan uang belum tentu hal yang sama. Dengan kata lain, memiliki karyawan yang bekerja dan menghasilkan keuntungan dari pekerjaan adalah secara berpotensi dua hal yang berbeda. Agil Sahir mengatakan bahwa mengaktifkan sumber daya dan memanfaatkan sumber daya adalah tidak sama. (Berapa banyak aktivitas nonproduktif yang ada dalam organisasi Anda?)

2. Bottlenecks yang sesungguhnya adalah sumber daya apapun yang memiliki kapasitas sama dengan atahu kurang dari permintaan yang diletakkan di atasnya. Dan non-bottleneck adalah sumber daya apapun yang memiliki kapasitas lebih besar dari permintaan yang diletakkan padanya. (Di mana bottlenecks yang "buruk" pada perusahaan Anda?)

3. Bottlenecks tidak selalu buruk - atahu baik, mereka hanya kenyataan dan harus dievaluasi untuk menentukan apakah mereka membantu atahu menghalangi secara keseluruhan sistem throughput. (Apakah Anda tahu apakah bottlenecks Anda baik atahu buruk?)

4. Bahwa kapasitas pabrik adalah sama dengan kapasitas bottlenecks-nya . (Anggap saja sebagai sekelompok pendaki yang hanya dapat berkembang/majusecepat pendaki yang paling lambat. Atahu bahwa tim ini hanya sekuat anggota terlemah.)

5. Perbaikan membutuhkan perubahan. Dan perubahan berarti ketidakpastian yang diterjemahkan ke dalam ketakutan. Ini adalah sifat manusia untuk berjuang untuk kontrol, prediktabilitas dan kepastian. (Berapa banyak dari apa yang Anda lakukan sebenarnya ditujukan terhadap perubahan?)

6. Bahwa dalam kenyataannya sejumlah kecil kendala mengatur kinerja secara keseluruhan. ( Apakah Anda tahu kendala utama yang menghambat Anda atahu organisasi Anda? )

7. Tidak memfokuskan semua energi pada perbaikan itu sendiri, tetapi lebih pada proses perbaikan. (Apakah perbaikan berkelanjutan dalam DNA organisasi Anda?)

8. Anda harus tahu apa tujuan Anda sebelum Anda dapat mengoptimalkan sistem (misalnya, diri sendiri, sebuah pabrik, tim, perusahaan, dll). Jika tidak ada, 
kemungkinan banyak kegiatan yang tidak produktif. ( Apa tujuan Anda? Apakah Anda benar-benar tahu apa itu ? Dan apakah Anda di jalan yang benar untuk mencapai itu?).

\section{KESIMPULAN}

Dari bahasan artikel diatas, dapat ditarik beberpa kesimpulan.

1. Tujuan

Mengidentifikasi tujuan perusahaan Perusahaan. Dengan hal ini Perusahaan kemudian memutuskan apa yang produktif dan apa yang tidak produktif. Apa pun yang bekerja menuju tujuan dianggap produktif.

2. Pengukuran

Pengukuran penting untuk menjaga catatan tentang bagaimana bisnis Perusahaan berjalan. Pastikan pengukuran ini akurat didefinisikan dalam hal tujuan perusahaan Perusahaan .

3. Berpikir kritis

Jadilah aktif dalam pencarian Perusahaan untuk pengetahuan. Carilah jawabanjawabannya, karena mereka tidak sering menghapiri Perusahaan. Bereksperimen dengan ide-ide sebelum menempatkan mereka ke dalam tindakan .

4. Teamwork

Tim sangat penting untuk berpikir kritis. Semakin banyak kepala pada pekerjaan akan lebih baik. Orang-orang memiliki pendapat yang berbeda dan pperusahaanngan yang berbeda seseorang dapat memikirkan sesuatu yang Perusahaan tidak akan pernah pikirkan.

5. Jangan pernah menyerah

Selalu ada kesempatan untuk datang kembali selama bisnis Perusahaan masih berjalan. Ketika Perusahaan menyerah adalah ketika Perusahaan kehilangan kesempatan Perusahaan dan bahkan untuk mencobanya.

6. Identifikasi

Pertama mengidentifikasi kendala di perusahaan Perusahaan. Sebuah kendala adalah sesuatu yang membatasi jumlah output perusahaan Perusahaan yang dapat dihasilkan

7. Exploit

Mencari tahu cara untuk mendapatkan lebih banyak produk dari kendala tanpa menggunakan kapasitas yang lebih. Ada banyak cara untuk melakukan hal ini, seperti dalam buku mereka mengubah istirahat makan siang sehingga kendala mesin bisa berjalan non-stop.

8. Bawahan (Subordinate)

Membuat penyesuaian terhadap sumber daya bukan kendala. Sumber daya bukan kendala dapat menghasilkan pada tingkat yang lebih tinggi daripada sumber daya kendala. Dengan membatasi seberapa banyak sumber daya bukan kendala akan membuat Perusahaan menurunkan biaya produk tercatat dengan menunggu sumber daya kendala berakhir.

9. Tinggikan (Elevate)

Ambil beberapa beban kerja berlebih dari Kendala tersebut. Kendala harus mampu menghasilkan pada atahu dekat dengan tingkat permintaan. Menggunakan 
sumber daya lain untuk memproduksi item-item kendala adalah cara yang baik untuk melakukan hal ini.

10. Ulangi

Mulai lagi pada lima langkah. Akan selalu ada kendala dalam bisnis yang membutuhkan perhatian. Semakin banyak kendala diidentifikasi dan tetap menghasilkan langkah-langkah yang lebih baik dari bisnis Perusahaan beroperasi.

\section{DAFTAR PUSTAKA}

Dorsey, D., \& Mueller-Hanson, R. (2017). Performance Management That Makes a Difference: An evidence-based approach. In Shrm. https://doi.org/10.1002/jssc.200800744

Goldratt, E. M., \& Cox, J. (2008). The Goal: A Process of Ongoing Improvement, Third Revised Edition (3th ed.). New York: New York : North River Press.

Goshu, Y. Y., Matebu, A., \& Kitaw, D. (2017). Development of Productivity Measurement and Analysis Framework for Manufacturing Companies. Journal of Optimization in Industrial Engineering, 10(22), 1-13. https://doi.org/10.22094/joie.2017.274

Islami, X., Mulolli, E., \& Mustafa, N. (2018). Using Management by Objectives as a performance appraisal tool for employee satisfaction. Future Business Journal, 4(1), 94-108. https://doi.org/10.1016/j.fbj.2018.01.001

Lutilsky, I. D., Liovic, D., \& Markovic, M. (2018). Throughput Accounting: ProfitFocused Cost Accounting Method. Interdisciplinary Management Research Xiv (Imr 2018), 14, 1382-1395.

Noronha, S. F., Aquinas, P. G., \& Manezes, A. D. (2016). Implementing Employee Performance Management System: A Scoping Review. International Journal of Management and Applied Science, 2(25), 85-89. Retrieved from http://www.iraj.in/journal/journal_file/journal_pdf/14-256-14650207648589.pdf

Pegels, C. C., \& Watrous, C. (2005). Application of the theory of constraints to a bottleneck operation in a manufacturing plant. Journal of Manufacturing Technology Management, 16(3), 302-311. https://doi.org/10.1108/17410380510583617

Qureshi, A., \& Hassan, M. (2013). Impact of performance management on the organisational performance: An analytical investigation of the business model of McDonalds. International Journal of Academic Research in Economics and Management Sciences, 2(5), 54-76. https://doi.org/10.6007/ijarems/v2-i5/299

Sari, R. M., Syahputri, K., Rizkya, I., \& Siboro, N. (2019). Optimization in Critical Work Center Using Theory of Constraints. IOP Conference Series: Materials Science and Engineering, 648(1). https://doi.org/10.1088/1757899X/648/1/012017

Setiyanto, A. I., \& Natalia. (2017). Impact of Work Environment on Employee Productivity in Shipyard Manufacturing Company. International Journal of Management \& IT, 2(1), 31-36. Retrieved from http://search.ebscohost.com/login.aspx?direct=true $\& d b=b t h \& A N=128869928$ $\&$ site $=$ ehost-live

Syverson, C. (2011). What determines productivity? Journal of Economic Literature, 
49(2), 326-365. https://doi.org/10.1257/jel.49.2.326

van der Hoek, M., Groeneveld, S., \& Kuipers, B. (2018). Goal Setting in Teams: Goal Clarity and Team Performance in the Public Sector. Review of Public Personnel Administration, 38(4), 472-493. https://doi.org/10.1177/0734371X16682815

Wang, Y., Zhao, Q., \& Zheng, D. (2005). Bottlenecks in production networks: An overview. Journal of Systems Science and Systems Engineering, 14(3), 347363. https://doi.org/10.1007/s11518-006-0198-3 